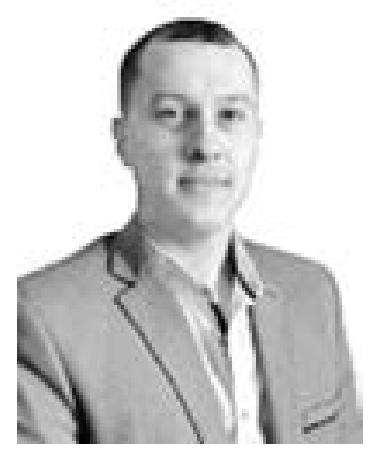

\title{
ПАРАДИГМА ЖОРСТОКОСТІ ТА КОРЕЛЯЦІЯ ДЕТЕРМІНАНТ «ЖОРСТОКІСТЬ», «НАСИЛЬСТВО», «AГPECIЯ"
}

БУНДЗ Ростислав Олегович - кандидат юридичних наук, асистент кафедри кримінального права і процесу Інституту права, психологіі та інноваційної освіти Національного університету «Львівська політехніка"

ORCID ID: https://orcid.org/ 0000-0002-3651-4068

УДК 343.6

DOI 10.32782/NP.2021.3.18

У cтатті, на основі чинного законодавства та контент аналізу наукових доробок, визначаються концептуальні підходи до визначення парадигми жорстокості та кореляціӥ детермінант «жорстокість», «насильство», агресія».

Зроблено висновки про те, що чинне законодавство чітко не регламентує дебініцію зазначених понять, $і$ це призводить до їх двоякого трактування, неправильної квалібікаизї та, відповідно, неналежного реагування державних органів на злочинні діяння.

Жорстокість - ие один із домінуючих індикаторів морального здоров'я нащї. Кількість злочинів насильницької мотивациї, пов'язаних з жорстокістю, садизмом, озлобленою агресивністю, ицнізмом, знущанням над потерпілими, щороку збільшується, вимагає посилення відповідальності за їх вчинення.

Охарактеризовано особливий тип поведінки особи, характерними специбіками якого виступають, власне, насильство, агресія $i$ жорстокість. Під жорстокістю, як ознакою окремих кримінальних правопорушень, належить розуміти невід'ємну особистісну рису, що проявляється в усвідомленому заподіянні бізичних, психічних чи моральних страждань (ии прагненні їх заподіяння), шляхом дї ии бездіяльності та є способом реалізацї агресії $і$ насильства.

Ключові слова: жорстокість, насильство, агресія, кримінальні правопорушення, шо вчиняються з особливою жорстокістю.

\section{Постановка проблеми}

Сучасне суспільство, враховуючи глобалізаційні передумови, егоцентризацію особистості, тотальне нівелювання загальноприйнятими нормами поведінки, вирізняється особливою жорстокістю, агресією та насильством. Жорстокість - це один із домінуючих індикаторів морального здоров'я нації. Безумовно, зазначені тенденції не виникли спонтанно та нізвідки, а вироблялись під впливом певних факторів упродовж останніх десятиліть. Кількість злочинів із насильницької мотивацією, коли насильство пов'язане з жорстокістю, садизмом, озлобленою агресивністю, цинізмом, знущанням над людьми, щороку збільшується, що вимагає посилення відповідальності за їх вчинення.

\section{Мета статті}

Дослідження феномену жорстокості в кореляції із насильством та агресією, моніторинг дотичних (однорідних) та відмінних платформ. Аналіз детермінант «жорстокість», «насильство», «агресія».

\section{Ступінь дослідженості теми}

Аналіз проблематики жорстокості проводиться перманентно у наукових дослідженнях у галузі філософії, соціології, психології, психіатрії, права, зокрема, в зазначене питання перебуває у центрі уваги таких учених: Ю. М. Антоняна, С. В. Бородіна, К. В. Катеринчука, В. І. Кучера, О. Ю. Михайлова, М. І. Райського, А. І. Скреклі, 
А. Д. Татарковського та ін. Проте, поняття жорстокості у працях науковців, зазвичай, розглядається під кутом певного складу кримінального правопорушення, що потребує постійного моніторингу та корегування оціночних підходів відповідно до норм чинного законодавства та вимог часу.

\section{Виклад основного матеріалу}

Феномен жорстокості був і $є$ притаманний будь-якому суспільству і майже завжди тісно пов'язаний із насильством і агресією. Це характерно і для сучасного етапу суспільного розвитку [1, с. 4]. Зокрема, Ю. М. Антонян слушно вважає, що вивчення агресивності й жорстокості вкрай необхідне, позаяк жорстокість, агресивність і насильство є дуже поширеними, а відтак, що глибшими будуть наші знання про них, їх причини, то успішніше зможемо боротися з ними [2].

Ще радикальніше висловлюється з цього приводу Н. Р. Хомичов, наголошуючи, що жорстокість необхідно викорінювати 3 нашого суспільства, боротися з нею треба так, щоб вона поступалася під натиском впливу на неї. Боротьба така має бути жорсткою [3]. У свою чергу, у рамках боротьби зі жорстокістю необхідно охопити такі питання, як: витоки жорстокості, її природу, зв'язок із агресією та насильством, а також заходи, які належить розробити для подолання цього негативного явища.

У сучасних умовах відсутня єдність у співвідношенні понять «жорстокість» та «особлива жорстокість» [4, с. 45]. У зв’язку з цим науковці виокремили два напрями вирішення цієї проблеми:

1) поняття жорстокості та особливої жорстокості ототожнюються [5, с. $54 ; 6$, c. 175-177];

2) особлива жорстокість характеризується винятковим характером і перевищує за своїм ступенем звичайну [7, с. 78-81].

Тим часом жорстокість проявляється порізному: дорослими щодо неповнолітніх; неповнолітніми стосовно дорослих; у сім'ї, побуті, школі, на вулиці, виробництві тощо. Вона доволі часто поєднана з агресією, різними формами насильства над особистістю. Однак ототожнювати поняття насильства, агресії і жорстокості неприпустимо. Адже жорстокість, на думку Н. В. Борисенкової [8, с. 13], є одним із проявів насильства.

Ю. М. Антонян [2], перестерігає від уніфікації зазначених понять, наголошуючи при цьому на їх тісному взаємозв'язку, а також на нагальності дослідження цих детермінант із позицій соціології, психології, психіатрії, моральності, права та генетики. Проте, щоразу феномен жорстокості виокремлюється ученим в особливий спосіб.

Відтак, аналізуючи кримінальні правопорушення, що вчиняються 3 особливою жорстокістю, а саме кримінологічний аспект цього питання, слід зважати на певні особливості. Зокрема, на нашу думку, можна говорити про таке поняття, як «кримінальна жорстокість».

Кримінальний кодекс України вказує на низку злочинів, кваліфікуючими ознаками яких 6 вчинення діяння «з особливою жорстокістю». Однак кримінологія, вважаємо, може розглядати прояв жорстокості набагато ширше, адже, вивчаючи кримінальні правопорушення, поєднані 3 жорстокістю, не можна обмежуватися лише «рекомендаціями» Кримінального кодексу. Кримінологія, досліджуючи реальність, зокрема, спираючись на практичний досвід, визначає своє коло злочинів, поєднаних із жорстокістю, яке значно ширше від представленого у Кримінальному кодексі України. У нього можуть бути включені, наприклад, і такі діяння, як побої, катування, хуліганство, деякі інші [2]. Варто також ураховувати, що при вчиненні цих кримінальних правопорушень, жорстокість тісно пов'язана $з$ насильством і агресією. I незалежно від того, поєднані злочини зі жорстокістю чи ні, основу їх вивчення мають становити не кримінально-правові догми, а кримінологічні знання, практичний досвід, реальність.

Як уже зазначалося, часто поняття жорстокості асоціюють із насильством і агресією. Позиції щодо поняття насильства $є$ дискусійними. У літературі зустрічаються як надмірно широкі, так і надто вузькі визначення насильства. До широких понять можна віднести розуміння насильства як поведінки, що завдає шкоди іншим; як примус, обмеження свободи вибору, «узурпація вільної волі» $[9$, с. 36$]$. За більш вузьким розумінням 


\section{Кримінальне право, кримінальний процес та криміналістика}

насильства, до нього належить заподіяння фізичної, психічної чи матеріальної шкоди.

Поняття «насильство» та «жорстокість» взаємопов’язані, оскільки жорстокість походить від насильства, однак за ступенем суспільної небезпеки є більш небезпечною. Така думка випливає з аналізу судової практики, де фантазія злочинця щодо обрання способу спричинення потерпілому фізичних та (або) моральних страждань неосяжна. Безумовно, всі кримінальні правопорушення, ознакою складів яких є жорстокість, насильницькі. Однак не всі насильницькі кримінальні правопорушення містять ознаку жорстокості. Вказівка законодавця в окремих диспозиціях статей саме на термін «жорстоке поводження», що має значення для кримінально-правової кваліфікації, а не на «насильство» свідчить про те, що є дії, які переходять межу насильства. Спільним, тобто таким що об'єднує жорстоке поводження і насильство, є спричинення потерпілому болю, страждань. Однак для жорстокого поводження характерним є бажання заподіяти страждання потерпілому, а також отримати задоволення від цього [10, с. 29].

На нашу думку, слушною $є$ позиціяЮ. М. Антоняна й В. В. Гульдана, які виокремлюють жорстокість в особливу категорію, позаяк вона «надає особливого забарвлення насильству й агресії, пов’язана зі способом їх реалізації, заподіянням жертві особливих страждань» [11, с. 15]. Жорстокість та агресивність, на думку вчених, розрізняються за ознакою «заподіяння страждань і мук заради страждань і мук», що властиве жорстокості і не властиве агресивності. Жорстокість як особистісна риса визначається відтак як «прагнення до заподіяння страждань і мук людям або тваринам, що виражається в діях, бездіяльності, словах, а також фантазуванні відповідного змісту». Акцентується, що агресивна людина може і не бути жорстокою, тоді як жорстока людина завжди агресивна.

3 цього приводу у Постанові Пленуму Верховного Суду України «Про судову практику в справах про злочини проти життя та здоров'я особи» зазначається, що умисне вбивство визнається вчиненим із особливою жорстокістю (п. 4 ч. 2 ст. 115
КК), якщо винний, позбавляючи потерпілого життя, усвідомлював, що завдає йому особливих фізичних (шляхом заподіяння великої кількості тілесних ушкоджень, тортур, мордування, мучення, в тому числі з використанням вогню, струму, кислоти, лугу, радіоактивних речовин, отрути, яка завдає нестерпного болю, тощо), психічних чи моральних (шляхом зганьблення честі, приниження гідності, заподіяння тяжких душевних переживань, глумлення тощо) страждань, а також якщо воно було поєднане із глумленням над трупом або вчинювалося в присутності близьких потерпілому осіб і винний усвідомлював, що такими діями завдає останнім особливих психічних чи моральних страждань [12].

Відтак, відсутність у законодавстві чіткого визначення окреслених понять спричиняє неправильну кваліфікацію та, відповідно, неналежне реагування органів держави на злочинні діяння.

«Емоційна неврівноваженість, марнославство, упертість, нечутливість до страждань інших людей, навіть близьких - усе це пов'язано зі жорстокістю і належить до найбільш поширених характерологічних рис неповнолітніх злочинців» [13, с. 55].Що примітивнішою є людина, стверджує А. В. Боков, то вона агресивніша [14, с. 33]. Багато що тут пов'язано $з$ розвитком маржиналізму. Це, по суті, вважає Ю. М. Антонян, люмпенізована частина населення, яка активно «постачає» неповнолітніх злочинців обох статей. Ці неповнолітні не вбачають у грубості і хамстві нічого особливого. Насильство, агресивна реакція на соціальні та психологічні «подразники», жорстокість у свідомості цієї категорії осіб сприймається як звичайна, звична, «природна» лінія поведінки [11]. Такі тенденції, як зазначаєТ. М. Ісаєнкова, виникають у злочинця, за правило, на грунті незадоволеності життям, внаслідок фрустрації і комплексів неповноцінності: «І чим більше збитковим відчуває себе винний, тим більшу жорстокість він може проявити при вчиненні злочину» [15].

Як уже зазначалося, багато вчених пишуть про жорстокість як властивість особистості неповнолітнього злочинця. У зв'язку зі жорстокістю виникає особливий тип по- 
ведінки, з'являється і особливий тип особистості, характерна риса якого власне насильство, агресія і жорстокість. Неповнолітні, що належать до такого типу особистості, поширюють серед своїх однолітків стереотипи агресивно-насильницької поведінки. Відтак, у комплексі причин і умов кримінальних правопорушень неповнолітніх, поєднаних iз жорстокістю і такими, що супроводжуються агресією, домінує відповідна особистість iз усіма притаманними їй властивостями, специфікою процесу формування та особливостями поведінки.

У цьому контексті надважливе значення має формування мотивації поведінки, тобто основу аналізу поєднаних зі жорстокістю злочинів неповнолітніх становить мотив діяння. У неповнолітніх, що вчиняють означені діяння, всі мотиви (заздрість, ненависть, помста, ревнощі тощо) акумулюються в двох основних напрямах: прагнення до реалізації мотиву злочину і досягнення кримінальної мети; прагнення до задоволення потреби в насильстві, що супроводжується жорстокістю. У таких неповнолітніх мотивація поведінки базується на вихідній меті кримінального правопорушення і конкретно спрямована на насильницький утиск потерпілого за допомогою жорстокості, що проявляється до нього. Вона зосереджена на насильстві, яке стимулює агресію і жорстокість. Часто ця жорстокість виходить за межі дії і зачіпає інтереси сторонніх осіб, що не мають стосунку до злочину.

Мотив злочину, поєднаного зі жорстокістю, має ніби подвійне підгрунтя: коли він є невід'ємною рисою особистості, йде зсередини, є властивістю особистості злочинця; коли він становить агресивну реакцією винного на «подразники» зі зовні від потерпілого. Зокрема, мотив злочину, поєднаного зі жорстокістю, спрямований на те, як, яким чином і за допомогою яких засобів можна «придушити» потерпілого. Він є власне реакцією на вказані «подразники», регулює спрямованість дій злочинця, а в процесі реалізації мотивованих дій - прагнення до прояву насильства і жорстокості. Цим, відтак і визначається здебільшого специфіка кримінальних правопорушень, поєднаних із жорстокістю.
Злочини, що розглядаються, об’єднані єдиним для них терміном - «пов'язані зі жорстокістю». Відповідно, визначаються критерії відмежування цієї частини кримінальних правопорушень від інших діянь. Однак парні зі жорстокістю злочини не становлять єдиного, недиференційованого масиву, хоча їх і об'єднує вказаний загальновживаний термін. Вони мають розвинену систему і відрізняються один від одного. Цілком допустима класифікація злочинів всередині цієї системи. Можлива і типологія (типізація) осіб, які вчиняють злочини, пов'язані зі жорстокістю.

Отже, можемо простежити певний зв'язок між поняттями «агресивність», «жорстокість» та «насильство». Усі ці явища слід віднести до особистісних рис, що проявляються під час вчинення кримінальних правопорушень. Насильство, безумовно, - це завжди злочин. Aле воно може бути i не жорстоким, як, скажімо, і агресивність, оскільки може вчинятись і шляхом бездіяльності. Aле це не означає, що жорстокою є лише активна злочинна поведінка. Наприклад, ненадання допомоги потерпілому, залишення без їжі, води чи в непридатних до життя умовах (залишення без одягу в холодну пору тощо) свідчать про жорстокість, позаяк такі діяння можуть спричинити потерпілому не менші страждання, ніж, наприклад, заподіяння значної кількості побоїв, завдання ударів тощо.

\section{Висновки}

Жорстокість як особистісна характеристика особи, як спосіб учинення злочину, як засіб досягнення злочинної мети завжди становила інтерес для практиків і теоретиків правоохоронної діяльності. На жаль, досі немає однозначного визначення терміна «жорстокість» та поняття «злочини, що вчиняються $з$ особливою жорстокістю».

Відтак під жорстокістю як ознакою злочинів належить розуміти невід'ємну особистісну рису особи, що проявляеться в усвідомленому заподіянні фізичних, психічних чи моральних страждань (чи прагненні їх заподіяння) шляхом дії чи бездіяльності та $є$ способом реалізації агресії і насильства. 


\section{Аітература}

1. Соломин Н. И. Агрессия и жестокость. М., 2005.

2. Антонян Ю. М. Жестокость в нашей жизни. М.: ИНФРА-М. 1995.

3. Хомичев Н. Р. Жестокость и ее распространение в молодежной среде. М.: «Просвещение», 2005. С. 156.

4. Кучер В. І. Кримінально-правові проблеми вчинення злочинів способом особливо жорстокого поводження: монографія / В. І. Кучер. К.: Азимут-Україна, 2004. 120 с.

5. Аниянц М. К. Ответственность за преступления против жизни по действующему законодательству союзных республик / М. К. Аниянц. М.: Юрид. лит., 1964. 212 с.

6. Загородников Н. И. Преступления против жизни по советскому уголовному праву / Н. И. Загородников. М.: Гос. изд-во юрид. лит., 1961. 276 с.

7. Таций В. Я. Понятие особой жестокости как квалифицирующего признака убийства / В. Я. Таций // Вопросы государства и права. М.: Юрид. лит. 1974. Вып. 2. C. $78-81$.

8. Борисенкова Н. В. Уголовно-правовая оценка жестокости: дис. ... канд. юрид. наук: спец. 12.00.08 «Уголовное право и криминология; уголовноисполнительное право» / Н. В. Борисенкова. М., 2005. 202 с.

9. Гусейнов А. А. Понятие насилия и ненасилия // А. А, Гусейнов / Вопросы философии. 1994. № 6.

10. Скрекля $\lambda$. I. Жорстокість, як наскрізне кримінально-правове поняття : дис. ... канд. юрид. наук: спец. 12.00.08 «Кримінальне право та кримінологія; кримінально-виконавче право» / ᄉ. І. Скрекля. Аьвів: Аьвівський державний університет внутрішніх справ. 2014. 219 с.

11. Антонян Ю. М, Бойко И. Б., Верещагин В. А. Насилие среди осужденных. М.: Юрист, 1994.
The article, based on current legislation and content analysis of scientific achievements, defines conceptual approaches to determining the paradigm of cruelty and the correlation of the determinants "cruelty", "violence", "aggression".

It is concluded that the current legislation does not clearly regulate the definition of these concepts, and this leads to their ambiguous interpretation, incorrect qualification and, accordingly, improper response of public authorities to criminal acts.

Cruelty is one of the dominant indicators of a nation's moral health. The number of violent crimes, when violence is associated with cruelty, sadism, bitter aggression, cynicism, and abuse of people, is increasing every year, which requires increased responsibility for their commission.

A special type of personality behavior is characterized, the characteristic features of which are, in fact, violence, aggression and cruelty. Cruelty as a sign of crime should be understood as an integral personal trait of a person, which is manifested in the conscious infliction of physical, mental or moral suffering (or the desire to inflict them) by action or inaction and is a way of aggression and violence.

Key words: cruelty, violence, aggression, crimes committed with special cruelty.

12. Про судову практику в справах про злочини проти життя та здоров'я особи: постанова Пленуму Верховного Суду України від 07.02.2003 № 2. URL: https://zakon.rada. gov.ua/laws/show/v0002700-03.

13. Ермаков В. Д., Крюкова Н. И. Несовершеннолетние преступники в России. Москва. 1999.

14. Боков А. В. Криминология и проблемы управления. Москва. 2005.

15. Исаенкова Т. Н. Мотивы убийств, сопряженных с разбоем и вымогательством. Преступное поведение (новые исследования): сб. науч. тр. Москва. 2002. 